\title{
Severe lower limb trauma
}

\section{Trauma grave em membro inferior}

\author{
Regis Pietro Acempcion \\ Guiraldo $^{1}$ \\ Cassiana Martins Cabral ${ }^{1}$ \\ Ricardo Thompson Nora ${ }^{2}$ \\ José Álvaro Lourenço \\ GASQUES $^{3}$ \\ Antonio Roberto Bozola ${ }^{4}$
}

This study was performed at the Plastic Surgery Service of Hospital de Base, São José do Rio Preto, SP, Brazil.

Submitted to SGP (Sistema de Gestão de Publicações/Manager Publications System) of RBCP (Revista Brasileira de Cirurgia Plástica/Brazilian Journal of Plastic Surgery).

Article received: September 27, 2011

Article accepted: June 1, 2012

\begin{abstract}
Severe trauma to the lower limbs, with major skin loss and the compromise of vital structures, is often difficult to treat. A combination of several factors such as ability and effort made to distinguish lesion severity - that is, to differentiate recoverable traumas from those that will inevitably progress to amputation - plays an important role. Therefore, indices were developed to facilitate the stratification of injury severity and prediction of the need for amputation, such as the Mangled Extremity Severity Score (MESS). In this article, we report a case of severe trauma to the lower limb, where reconstruction was performed based on the MESS index with multiple muscle flaps, and a good functional outcome was achieved.
\end{abstract}

Keywords: Lower extremity. Leg injuries. Reconstructive surgical procedures. Amputation. Surgical flaps. Trauma severity indices.

\section{RESUMO}

Traumatismos graves de membros inferiores, com grandes perdas cutâneas e comprometimento de estruturas vitais, são casos de difícil resolução. A combinação de vários fatores, como esforço realizado e capacidade de distinguir a gravidade das lesões, ou seja, diferenciar as lesões recuperáveis ou viáveis daquelas que inevitavelmente irão evoluir para amputação, tem importante papel. Para tanto, surgiram índices que buscam estratificar a gravidade da lesão e predizer a necessidade de amputação, como o índice MESS (do inglês, Mangled Extremity Severity Score). Neste artigo, é reportado um caso de trauma grave de membro inferior, com reconstrução baseada no índice MESS, com emprego de múltiplos retalhos musculares e boa evolução funcional.

Descritores: Extremidade inferior. Traumatismos da perna. Procedimentos cirúrgicos reconstrutivos. Amputação. Retalhos cirúrgicos. Índices de gravidade do trauma.

\section{INTRODUCTION}

The treatment of patients with severe trauma to the lower limbs often represents a challenge for surgeons. The decision of whether to retrieve or amputate the affected limb is often a dilemma in practice. Due to the recent advances in microsurgical techniques associated with modern repair, limb recovery has become possible. However, when opting to save the limb, one should also consider high morbidity rates, high costs, and the possibility of mortality.

In an attempt to establish criteria for avoiding limb amputation and instead working to restore its viability and function, indices - such as the Mangled Extremity Severity Score (MESS), which has been widely used since its introduction in $1987^{1,2}$ - have been developed to stratify injury severity and predict the need for amputation. A

1. Plastic surgeon, associate member of the Sociedade Brasileira de Cirurgia Plástica (Brazilian Society of Plastic Surgery - SBCP), a former resident of the Plastic Surgery Service of Hospital de Base, São José do Rio Preto, SP, Brazil.

2. Aspiring member in training of SBCP, resident physician of the Plastic Surgery Service of Hospital de Base, São José do Rio Preto, SP, Brazil

3. Plastic surgeon, full member of SBCP, chief of the Plastic Surgery Service of Hospital de Base, São José do Rio Preto, SP, Brazil.

4. Plastic surgeon, full member of the SBCP, Professor Doctor in Plastic Surgery, regent of the Plastic Surgery Service of Hospital de Base, São José do Rio Preto, SP, Brazil. 
MESS of $\geq 7$ indicates a positive predictive value of $100 \%$ for amputation ${ }^{3}$.

In the present study, we aimed to report the case of a patient who experienced severe lower limb trauma in which reconstruction was based on the MESS index and involved the use of multiple muscle flaps.

\section{CASE REPORT}

A 72-year-old woman presented with hypertension after being hit by a truck. No loss of consciousness was reported. The patient was initially treated at the Santa Casa de Votuporanga, located $89 \mathrm{~km}$ from São José do Rio Preto, and was hemodynamically stable with a score of 15 on the Glasgow coma scale. She was directed through the Central State Vacancies for evaluation of a serious injury in the right leg (Figure 1).

On admission to the Hospital de Base, São José do Rio Preto, the patient exhibited stable vital signs, blood pressure of $96 \times 56 \mathrm{mmHg}$, heart rate of 70 beats per minute, respiratory rate of 18 breaths per minute, and Glasgow coma score of 15. Upon examination of the lower limbs, crushing and degloving of the right lower limb at the infragenicular level with exposure of the tibia and fibula without tendon injuries and no palpable distal pulses were noted (Figure 2). Radiography indicated the absence of fractures. The assessment by the vascular surgery team using Doppler imaging detected flow in the posterior tibial artery; however, a subsequent arteriography showed only a patent peroneal artery with occluded anterior and posterior tibial arteries. An identical pattern was observed in the non-traumatized contralateral limb with the exception of the traumatic arterial lesions.

The patient underwent reconstructive surgery that required 9 hours, wherein gastrocnemius, tibial, and sural muscle flaps were used. The accident had caused several muscle injuries and bone exposure (Figure 2), and the injured viable muscles were used as flaps. The surgical procedure was completed by covering the muscles with skin grafts by using degloved skin (Figure 3). At the end of the surgery, a compressive dressing was placed in the grafted area. During the 7-day hospitalization period, the patient received antibiotic therapy with clindamycin (600 mg, every 8 hours) and
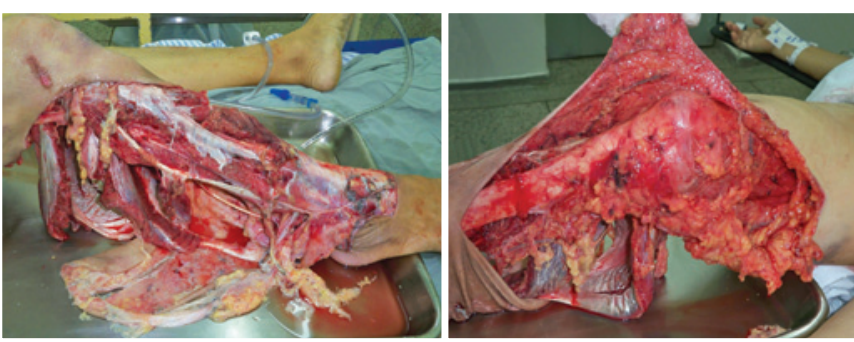

Figure 1 - Preoperative appearance. garamycin (240 mg/day), and also received analgesia and prophylactic treatment with heparin.

The patient was followed by the outpatient staff of Plastic Surgery and Physiotherapy, who applied adaptic and hydrogel dressings. The patient underwent another surgery 102 days after the initial procedure, with the placement of new partial skin grafts in areas where no attachment between the primary grafts and the donor area of the right thigh was observed. After complete lesion healing, the use of medium compression stockings and intensified physiotherapy was prescribed.

The patient was followed up as an outpatient and underwent physical therapy for 17 months. She walks with the help of braces and has sensitivity in the limb as well as dorsiflexion of the foot and toe extension. The patient exhibited a limitation of the range of knee flexion at $80^{\circ}$.

\section{DISCUSSION}

Severe lower limb trauma with major skin loss and the compromise of vital structures is difficult to treat. The early

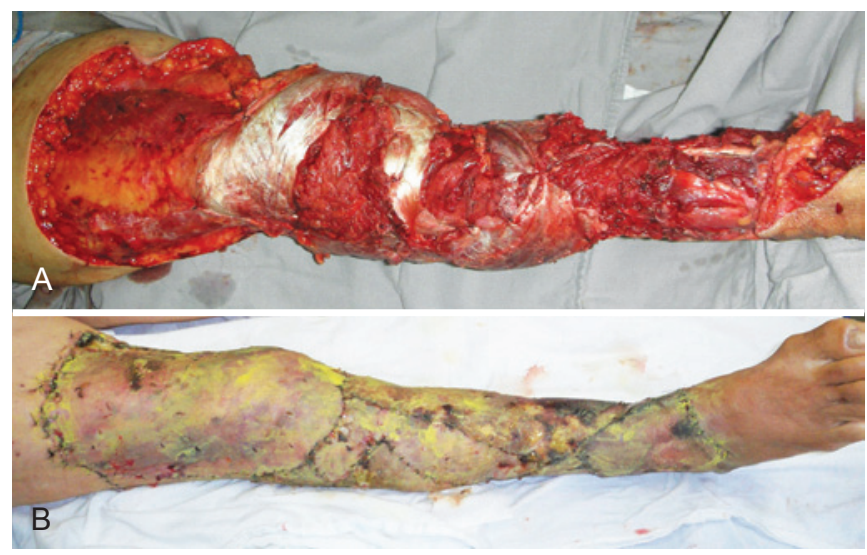

Figure 2 - Immediate postoperative appearance of muscle flaps. In $\boldsymbol{A}$, appearance before skin grafting. In $\boldsymbol{B}$, appearance after skin grafting.

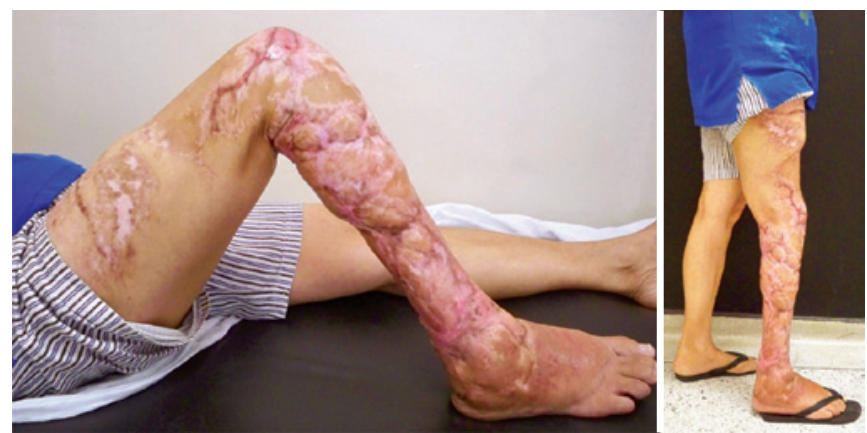

Figure 3 - Postoperative appearance 12 months after surgery with muscle flaps and skin grafts. 
and definitive reconstruction of complex trauma of the limbs was introduced in Ljubljana, Slovenia, by Godina ${ }^{4}$, who since 1976 - has performed reconstruction using microsurgical flaps in the first 72 hours after injury but before the onset of fibrosis.

After several years, certain limitations remain, both in terms of material and technique, which prevent the widespread application of free flaps in emergency cases. These procedures are costly and require specialized teams ${ }^{5}$. There is a need not only to cover the wound, but also to ensure joint mobility, deambulation, and a return to normal activities. Several studies have increasingly indicated the development of cutaneous coverage.

In 1994, Zumiotti et al. ${ }^{6}$ presented the results of coverage with free flaps in 27 patients with open fractures. It was the first publication in the Brazilian literature of the use of free flaps in emergency cases.

Recent advances in microsurgical techniques - both in the broad field and in the procedures related to the vascular peripheral nervous system - that are associated with modern techniques of bone repair as well as fixation methods such as Ilizarov's, have allowed for the recovery of limbs in many cases that would have undergone amputation at previous instances ${ }^{7}$.

The experience gained in several specialized centers, with the recovery of these "revascularized" limbs, now allows for the careful and thorough assessment of the clinical results presented.

However, several studies have surprisingly indicated that, in certain cases, the attempted recovery was less satisfactory than that obtained or expected by immediate amputation ${ }^{7}$. This makes the decision to be made by the surgeon at the time of initial patient care and during the course of treatment even more difficult. Given the gravity of the issue, a combination of factors such as the effort made and the ability to distinguish lesion severity - that is, differentiate recoverable viable lesions from those that will inevitably progress to amputation - plays an important role. The goal is to ensure that the decision of keeping the limb is not postponed indefinitely, which may result in significant increase in morbidity, mortality, hospital costs, and psychological trauma to the patient. However, it may be difficult to take this decision while ensuring an acceptable safety margin.

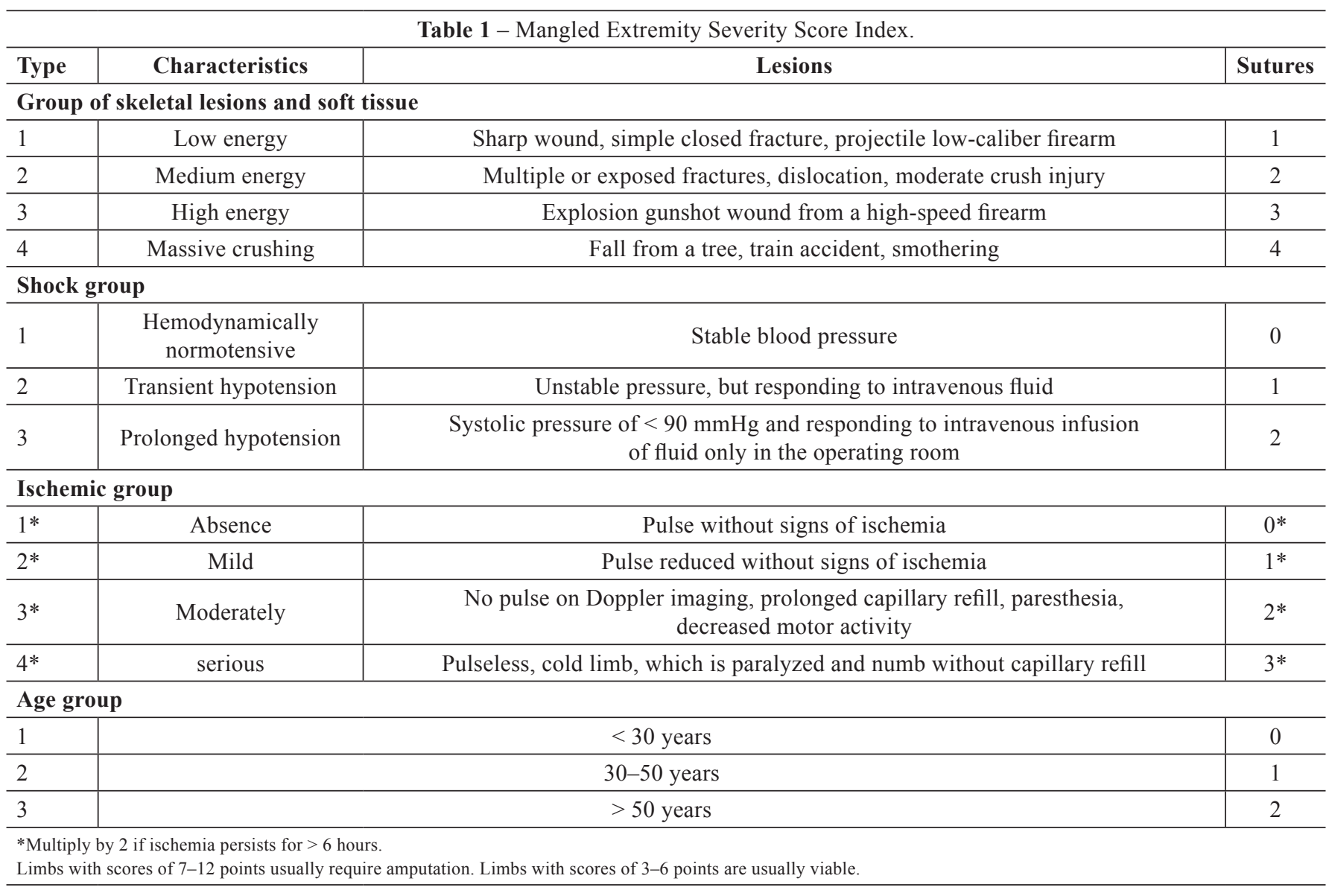


Several authors have been concerned with these issues, and seek to establish criteria to define successful reconstruction or immediate amputation ${ }^{1,2,8-10}$. To answer these questions, in 1987, Helfet et al. ${ }^{1}$ and Sanders et al. ${ }^{2}$ created a classification system to determine the extent of damage, termed as the MESS index. In 1990, these authors published their first results, which involved a comparison of retrospective and prospective data demonstrating that a score of $\geq 7$ was correlated with $100 \%$ amputation ${ }^{3}$.

The use of the MESS index is widespread in several trauma centers, and analysis of the outcomes will be essential to obtain answers in difficult cases and also to establish objective criteria to assist in decision making. Although several studies have questioned the dogmatic character of this system, it has proven to be reliable in practice.

McNamara et al. ${ }^{11}$, of the University of Texas, confirmed the index score of $\geq 7$ as an indicative value of amputation, and concluded that the MESS index is highly accurate $(\mathrm{P}<0.005)$ in deciding whether amputation should be performed.

There is a solid foundation in the literature as well as recent research on the fact that limbs presenting with "hot" ischemia for intervals longer than $6 \mathrm{~h}$, especially in lesions with crushing, do not progress well.

The patient reported in this paper showed a MESS index of 6 at initial presentation (Table 1).

In patients with isolated limb trauma without other associated severe injuries, which have an MESS index score of $<7$, limb preservation should be attempted. The mul- tidisciplinary approach is of the utmost importance for achieving good functional recovery and rehabilitation of the patient.

\section{REFERENCES}

1. Helfet DL, Howey T, Sanders R, Johansen K. Limb salvage versus amputation. Preliminary results of the Mangled Extremity Severity Score. Clin Orthop Relat Res. 1990;(256):80-6.

2. Sanders R, Swiontkowski MF, Nunley JA $2^{\text {nd }}$, Spiegel PG. The management of fractures with soft-tissue disruptions. Instr Course Lect. 1994;43:559-70.

3. Johansen K, Daines M, Howey T, Helfet D, Hansen ST Jr. Objective criteria accurately predict amputation following lower extremity trauma. J Trauma. 1990;30(5):568-72.

4. Godina M. Early microsurgical reconstruction of complex trauma of the extremities. Plast Reconstr Surg. 1986;78(3):285-92.

5. Ferreira MC, Besteiro JM, Monteiro Júnior AA, Zumiotti A. Reconstruction of the foot with microvascular free flaps. Microsurgery. 1994; 15(1):33-6.

6. Zumiotti A, Ohno P, Guarnieri M. O emprego de retalhos microcirúrgicos na urgência. Rev Bras Ortop. 1994;29(4):231-5.

7. Lourenço PRB, Franco JS. Atualização no tratamento das fraturas expostas. Rev Bras Ortop. 1998;33(6):436-46.

8. Dirschl DR, Dahners LE. The mangled extremity: when should it be amputated? J Am Acad Orthop Surg. 1996;4(4):182-90.

9. Hansen ST. The type-IIIC tibial fracture. Salvage or amputation. J Bone Joint Surg Am. 1987;69(6):799-800.

10. Howe HR Jr, Poole GV Jr, Hansen KJ, Clark T, Plonk GW, Koman LA, et al. Salvage of lower extremities following combined orthopaedic and vascular trauma. A predictive salvage index. Am J Surg. 1987;53(4): 205-8.

11. McNamara MG, Heckman JD, Coeley FG. Severe open fractures of the lower extremity: a retrospective evaluation of the Mangled Extremity Severity Score (MESS). J Orthop Trauma. 1994;8(2):81-7.

\section{Correspondence to:}

Antonio Roberto Bozola

Av. Brigadeiro Faria Lima, 5416 - Vila São Pedro - São José do Rio Preto, SP, Brazil - CEP 15090-000

E-mail: ceplastica@hotmail.com 